Article

\title{
Compounds from Terminalia mantaly L. (Combretaceae) Stem Bark Exhibit Potent Inhibition against some Pathogenic Yeasts and Enzymes of Metabolic Significance
}

\author{
Marthe Aimée Tchuente Tchuenmogne ${ }^{1}$, Thierry Kammalac Ngouana ${ }^{2}$, \\ Sebastian Gohlke ${ }^{3}$, Rufin M. T. Kouipou ${ }^{2}$, Abdulselam Aslan ${ }^{4}$, Muslum Kuzu ${ }^{5}$, \\ Veysel Comakli ${ }^{6}$, Ramazan Demirdag ${ }^{6}$, Silvère A. Ngouela ${ }^{1}$, Etienne Tsamo ${ }^{1}$, \\ Norbert Sewald ${ }^{3}$, Bruno N. Lenta ${ }^{7}$ and Fabrice F. Boyom ${ }^{2, *}$
}

1 Laboratory of Natural Products and Organic Synthesis, Department of Organic Chemistry, Faculty of Science, University of Yaoundé 1, Box: 812, Yaoundé, Cameroon; tch_aimee@yahoo.fr (M.A.T.T.); sngouela@yahoo.fr (S.A.N.); tsamoet@yahoo.fr (E.T.)

2 Antimicrobial \& Biocontrol Agents Unit, Laboratory for Phytobiochemistry and Medicinal Plants Studies, Department of Biochemistry, Faculty of Science, University of Yaoundé I, Yaoundé P.O. Box: 812, Yaoundé, Cameroon; ngouanathi@yahoo.com (T.K.N.); toghueo.rufin@yahoo.fr (R.M.T.K.)

3 Chemistry Department, Organic and Bioorganic Chemistry, Bielefeld University, P.O. Box 100131, D-33501 Bielefeld, Germany; sebastian.gohlke@uni-bielefeld.de (S.G.); norbert.sewald@uni-bielefeld.de (N.S.)

4 Giresun University, Faculty of Engineering, Department of Industrial Engineering, 28200 Giresun, Turkey; abdulselam@hotmail.de

5 Agrı Ibrahim Cecen University, Faculty of Pharmacy, Department of Basic Pharmaceutical Sciences, 04100 Agri, Turkey; mkuzu@agri.edu.tr

6 Agr1 Ibrahim Cecen University, School of Health, Department of Nutrition and Dietetics, 04100 Agri, Turkey; veysel_comakli@hotmail.com (V.C.); r.demirdag@hotmail.com (R.D.)

7 Department of Chemistry, Higher Teacher Training College, University of Yaoundé 1, Yaoundé, Cameroon; lentabruno@yahoo.fr

* Correspondence: fabrice.boyom@fulbrightmail.org

Abstract: The chemical investigation of the anti-yeast methanol extract from the stem bark of Terminalia mantaly led to the isolation of seven compounds: 3-O-methyl-4-O- $\alpha-$ rhamnopyranoside ellagic acid (1), 3-O-mehylellagic acid (2), arjungenin or 2,3,19,23tetrahydroxyolean-12-en-28-oïc acid (3), arjunglucoside or 2,3,19,23-tetrahydroxyolean-12-en-

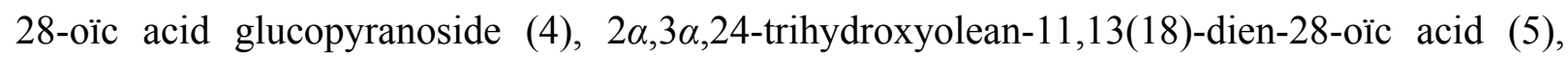
stigmasterol (6), stigmasterol 3-O- $\beta$-D-glucopyranoside (7). Their structures were established by means of spectroscopic analysis and comparison with published data. Compounds 1-5 were 
tested in vitro for activity against three pathogenic yeast isolates, Candida albicans, Candida parapsilosis and Candida krusei. The activity of compounds 1, 2 and 4 were comparable to that of the reference compound fluconazole (MIC values below $32 \mu \mathrm{g} / \mathrm{ml}$ ) against the three tested yeast isolates. They were also tested for inhibitory properties against four enzymes of metabolic significance: Glucose-6-Phosphate Deshydrogenase (G6PD), human erythrocyte Carbonic anhydrase I and II (hCA I and hCA II), Glutathione S-transferase (GST). Compound 4 showed highly potent inhibitory property against the four tested enzymes with overall $\mathrm{IC}_{50}$ values below $4 \mu \mathrm{M}$ and inhibitory constant (Ki) $<3 \mu \mathrm{M}$.

Keywords: Anti-yeast; Enzyme inhibitors; Terminalia mantaly; Combretaceae

\section{Introduction}

Fungal diseases affect every year 3-4 million people worldwide. Of particular importance, the increasing resistance of pathogenic opportunistic yeasts to current drugs is a serious concern and has attracted the attention of the scientific community. New, safe, and costeffective drugs of natural or synthetic origin are therefore actively being searched [1]. Recent epidemiological data highlight the increasing burden of pathogenic yeasts on people in poor settings [2,3,4]. Candida species and Cryptococcus neoformans are the major pathogenic yeasts and only few antifungal drugs have been developed so far to treat the invasive infections they cause $[5,6]$. Medicinal plants have shown credibility as sources of treatment for infectious diseases [7]. In Cameroon, extracts from medicinal plants such as Terminalia mantaly (Combretaceae) are widely used by traditional healers to control diverse infections or associated symptoms, including but not limited to dysentery, gastroenteritis, hypertension, diabetes, and oral, dental, cutaneous and genital affections [8]. Previous studies on the extracts of this plant have indicated antibacterial and antifungal properties, but their chemical compositions have not yet been determined. However, phytochemical studies of other species of the genus Terminalia have reported the presence of flavonoids, terpenoids and their glycosides derivatives, tannins, flavonones and chalcones [9-18]. Besides, in spite of the work done on Terminalia species, no investigation has been attempted yet on the enzyme inhibition properties of their extracts and constituents targeting Glucose-6-phosphate dehydrogenase, Carbonic anhydrase and Glutathione S-transferase. 
Glucose-6-phosphate dehydrogenase (G6PD; E.C. 1.1.1.49) enzyme catalyzes the reaction of glucose-6-phosphate into phosphogluconate, which is the first step of rate-limiting of pentose phosphate pathway. The end products of this pathway are ribose-5-phosphate and NADPH. Ribose-5-phosphate is used in DNA or RNA synthesis in cell reproduction, and $\mathrm{NADPH}$ is used as coenzyme for the enzymes participating in the production of reduced glutathione. Given its role in cell growth, this enzyme is of high importance to mammal cells $[19,20]$. However, several studies have shown that this enzyme takes an important role in the pathology of some diseases like cancer, hypertension, heart failure and type 2 diabetes. G6PD activity increases in cancer cells and its inhibition results in decrease of cell proliferation and induction of apoptosis. For example, 6-aminonicotinamide which is an inhibitor of G6PD has found use in the therapy of various tumors in the past [21].

Carbonic anhydrase (CA; carbonate hydro-lyase, EC 4.2.1.1) enzyme exists commonly in living organisms, and has various isoenzymes according to conditions and necessities of the medium. It is one of the most studied enzymes and CA-I and CA-II are the most common isoenzymes [22]. In many physiological and pathological processes, CAs catalyze the conversion of $\mathrm{CO}_{2}$ to $\mathrm{HCO}_{3}{ }^{-}$and $\mathrm{H}^{+}$. In addition, $\mathrm{CA}$ inhibitors may be used in the treatment of various diseases such as oedema, glaucoma, obesity, cancer, epilepsy and osteoporosis [23].

In living cells, the deleterious effects of free radicals and their intermediates are eliminated or minimized by various enzymatic and non-enzymatic defense systems. Enzymatic defense is provided by several enzymes such as glutathione S-transferase (GST), glutathione reductase, glutathione peroxidase, superoxide dismutase, and catalase [24]. The GSTs (EC 2.5.1.18) are a group of multifunctional enzymes that play an important role in the metabolism [25]. GSTs are important for the fight against cancer because of their interactions with carcinogens and chemotherapeutic agents. They are the target of antiasthmatic and antitumor drugs [26]. Production of excessive amounts of GST in mammalian tumor cells leads to resistance to some anticancer drugs and chemical carcinogens [27].

The reduction of drugs effects in tumor cells is an important factor limiting the therapeutic efficacy of an antineoplastic agent. The development of this resistance was associated with glutathione (GSH) and glutathione S-transferase (GST) levels in cells and changes in permeability to the drug. In this regards, G6PD, CA I, II or GST inhibitors may be useful because of their several applications, in particular for the treatment of glaucoma, epilepsy, cancer and as diuretics.

In our search for bioactive secondary metabolites from Cameroonian medicinal plants, we have investigated the $\mathrm{MeOH}$ extract of the stem bark of Terminalia mantaly L. 
(Combretaceae) that previously showed anti-yeast activity. We report in this paper the inhibitory potential of compounds isolated from this extract against some pathogenic yeasts and some enzymes of metabolic significance.

\section{Materials and methods.}

\subsection{General Experimental Procedures}

Optical rotations were measured on a JASCO digital polarimeter (model DIP-3600). UV spectra were determined on a Spectronic Unicam spectrophotometer. IR spectra were determined on a JASCO Fourier transform IR-420 spectrometer. ${ }^{1} \mathrm{H}$ and ${ }^{13} \mathrm{C}$ NMR spectra were run on a Bruker spectrometer equipped with $5 \mathrm{~mm}{ }^{1} \mathrm{H}$ and ${ }^{13} \mathrm{C}$ probes operating at 500 and 125 $\mathrm{MHz}$, respectively, with TMS as internal standard. Silica gel 230-400 mesh (Merck) and silica gel 70-230 mesh (Merck) were used for flash and column chromatography while precoated aluminum backed silica gel 60 F254 sheets were used for TLC. Spots were visualized under UV light (254 and $365 \mathrm{~nm}$ ) or using $\mathrm{MeOH}-\mathrm{H}_{2} \mathrm{SO}_{4}$ reagent.

\subsection{Plant Material}

The stem bark of Terminalia mantaly (Combretaceae) was collected in Yaoundé in May 2012 and identified at the Cameroon National Herbarium where a voucher specimen is deposited under the reference $\mathrm{N}^{\circ}$ 64212/HNC (Terminalia mantaly H. Perrier).

\subsection{Microbial isolates}

Yeast isolates were generously provided by the Laboratory of Clinical Biology, Yaoundé Central Hospital and consisted of clinical isolates of Candida albicans, Candida krusei and Candida parapsilosis. These yeasts were maintained at room temperature and cultured at $37^{\circ} \mathrm{C}$ for 24 hours on Sabouraud Dextrose Agar (Oxoid) slants prior to use.

\subsection{Plant extraction and screening of anti-yeast activity}

The harvested T. mantaly stem bark was dried at room temperature and ground using a blender. The powdered stem bark (7 kg) was extracted at r.t. with $\mathrm{MeOH}(48 \mathrm{~h})$. The extract was concentrated under vacuum to afford a dark residue $(250 \mathrm{~g})$. Minimal Inhibitory Concentration (MIC) of the extract was determined according to the CLSI M27-A3 [6] protocol with little modifications. The RPMI 1640 supplemented with $2 \%$ glucose was used as culture medium. Briefly for the fungal susceptibility tests, $50 \mu \mathrm{L}$ of serially 2 -fold diluted concentrations of the crude extract were added in triplicate wells of a 96-wells microtiter plate. 
Fifty $\mu \mathrm{L}$ of fungal inocula standardized to a final concentration of $0.5-2.5 \times 10^{3} \mathrm{CFU} / \mathrm{mL}$ were then individually added in each well of the plate. Plant crude extract and the positive control (fluconazole) at concentrations of 0.12 to $64 \mu \mathrm{g} / \mathrm{mL}$ were tested in a final volume of $100 \mu \mathrm{L}$. So-prepared plates were incubated at $37{ }^{\circ} \mathrm{C}$ for 48 hours. MIC value was subsequently determined through macroscopic observation of plate wells, and was defined as the lowest concentration of the inhibitor that allowed no visible growth of the microorganism.

\subsection{Isolation of compounds and screening for activity}

A portion of $180 \mathrm{~g}$ of the extract was subjected to medium pressure flash chromatography over silica gel (Merck, 70 - 230 mesh) using mixtures $n$-hexane-EtOAc of increasing polarity $[(70: 30)-(0: 100)]$ and EtOAc-MeOH $[(95: 5)-(50: 50)]$, resulting in the collection of 75 fractions of $500 \mathrm{~mL}$ each, which were combined on the basis of TLC analysis to afforded 4 fractions labeled $\mathrm{T}_{1}-\mathrm{T}_{4}$. Fraction $\mathrm{T}_{1}(\mathrm{~m}=14,4 \mathrm{~g})$ obtained from the mixtures of $n$ hexane-EtOAc (100:0 to 70:30) was subjected to silica gel column chromatography eluted with $n$-hexane-EtOAc and yielded oils, stigmasterol (6, $23 \mathrm{mg})$ and arjungenin $(3,7 \mathrm{mg})$. From fraction $\mathrm{T}_{2}(\mathrm{~m}=60,3 \mathrm{~g})$, eluted with $n$-hexane-EtOAc $[(50: 50)-(25: 75)]$, stigmasterol 3-O- $\beta$ D-glucopyranoside (7, $12 \mathrm{mg})$, arjungenin (3, $17 \mathrm{mg}), 2 \alpha, 3 \alpha, 24$-trihydroxyolean-11,13(18)dien-28-oic acid (5, $5.0 \mathrm{mg})$ and arjunglucoside $(4,6 \mathrm{mg})$ were isolated. Column chromatography of fraction $\mathrm{T}_{3}(\mathrm{~m}=55.0 \mathrm{~g})$ on silica gel and eluted with the mixtures of EtOAc$\mathrm{MeOH}[(100: 0)-(85: 15)]$, yielded 3-O- methylellagic acid 4'-O- $\alpha$-rhamnopyranoside (1, 32 $\mathrm{mg})$, arjungenin $(3,12.0 \mathrm{mg})$, arjunglucoside $(4,3,5 \mathrm{mg}), 2 \alpha, 3 \alpha, 24$-trihydroxyolean-11,13(18)dien-28-oic acid $(5,3.5 \mathrm{mg})$ and a dark mixture that was subjected to column chromatography on Sephadex LH-20 with $\mathrm{MeOH}$ as isocratic eluent and yielded 3-O-methyl ellagic acid (2, $12,5 \mathrm{mg})$. Fraction $\mathrm{T}_{4}(\mathrm{~m}=81.8 \mathrm{~g})$ obtained with the mixtures of EtOAc-MeOH $(85: 15$ to 65:35) was a complex mixture and thus were not studied. All the isolated compounds were screened as described above for anti-yeast activity, and as described below for enzyme inhibition activities.

\subsection{Purification of Glucose 6-Phosphate Dehydrogenase and activity determination}

G6PD was purified from the gill tissue of Lake Van fish according to Kuzu et al. [28], and the enzyme activity was determined spectrophotometrically using a Shimadzu spectrophotometer (UV-1800) at $25{ }^{\circ} \mathrm{C}$, according to the method described by Beutler [29] and based on the principle of the reduction of $\mathrm{NADP}^{+}$to NADPH in the presence of glucose 6phosphate and absorbance recorded at $340 \mathrm{~nm}$. 


\subsection{Purification of carbonic anhydrase isoenzymes by affinity chromatography and activity determination}

The purification of hCA I and II isozymes was performed with a simple one step method by a Sepharose-4B anilinesulfanilamide affinity column chromatography as previously described [30].

The esterase activity was assessed following the change in absorbance of 4nitrophenylacetate (NPA) to 4-nitrophenylate ion at $348 \mathrm{~nm}$ over a period of $3 \mathrm{~min}$ at $25{ }^{\circ} \mathrm{C}$ using a spectrophotometer (Beckman Coulter UV-VIS) according to the method described by Verpoorte et al. [31].

\subsection{Purification of Glutathione -S Transferase enzyme and activity determination}

Firstly, heamolysate from human erythrocytes was prepared according to the method of Hunaiti et.al. [32]. The prepared heamolysate was directly applied to the glutathione-agarose affinity column and washed with $10 \mathrm{mM} \mathrm{KH}_{2} \mathrm{PO}_{4}$ and $0.1 \mathrm{M} \mathrm{KCl}(\mathrm{pH} \mathrm{8.0)}$. The washing procedure was monitored on a spectrophotometer through equal-to-blind absorbance values. After the column was stabilized, the enzyme was purified by gradient elution at $+4^{\circ} \mathrm{C}[24,33]$. Elution solvent was prepared from a solvent gradient containing $50 \mathrm{mM}$ Tris- $\mathrm{HCl}$ and (1.25$10 \mathrm{mM}$ GSH, $\mathrm{pH}$ 9.5). Thereafter, 1-chloro-2,4-dinitrobenzene was used to determine GST enzyme activity. In fact the product obtained using this substrate, dinitrobenzene $S$-glutathione (DNB-SG) displays maximum absorbance at $340 \mathrm{~nm}$. Activity measurements were thus carried out using the absorbance increment at this wavelength. [34].

\subsection{In vitro inhibition and Kinetic studies}

To determine the effects of compounds on enzymes, enzymes activities were measured with saturated substrate concentration and five different inhibitor concentrations. The 50\% inhibitory concentrations $\left(\mathrm{IC}_{50}\right)$ were determined by plotting curves of \% inhibition versus compound concentration. Results are reported as $\mathrm{IC}_{50}$ values. $\mathrm{Ki}$ constants were calculated using the Cheng-Prusoff equation [35].

\section{Results and Discussion}

The methanol extract of the stem bark of Terminalia mantaly was screened for antiyeast activity in vitro against three clinical isolates consisting of Candida albicans, Candida 
krusei and Candida parapsilosis. The crude extract exhibited good activity with MIC values of $24 \mu \mathrm{g} / \mathrm{mL}$ against $C$. parapsilosis and $39 \mu \mathrm{g} / \mathrm{mL}$ against $C$. albicans and $C$. krusei (Table 1).

Table 1: Anti-yeast activity of Terminalia mantaly extract and isolates

\begin{tabular}{|c|c|c|c|}
\hline & C. parapsilosis & C. albicans & C. krusei \\
\hline & \multicolumn{3}{|c|}{$* \mathrm{MIC}(\mu \mathrm{g} / \mathrm{mL} \pm \mathrm{SD})$} \\
\hline $\mathrm{MeOH}$ Extract & $24.00 \pm 0.21$ & $39.00 \pm 0.33$ & $39.00 \pm 0.30$ \\
\hline Fraction $\mathrm{T} 1$ & $1250.00 \pm 1.23$ & $2500.00 \pm 0.98$ & $2500.00 \pm 1.03$ \\
\hline Fraction $\mathrm{T} 2$ & $39.00 \pm 0.38$ & $>5000$ & $>5000$ \\
\hline Fraction $\mathrm{T} 3$ & $0.16 \pm 0.02$ & $0.64 \pm 0.12$ & $0.02 \pm 0.09$ \\
\hline Fraction T4 & $>5000$ & $>5000$ & $>5000$ \\
\hline 1 & $\begin{array}{l}39.00 \pm 0.88(80.4 \\
\mu \mathrm{M})\end{array}$ & $9.70 \pm 0.72(20 \mu \mathrm{M})$ & $>5(10.30 \mu \mathrm{M})$ \\
\hline 2 & $\begin{array}{l}78.00 \pm 0.92(247.6 \\
\mu \mathrm{M})\end{array}$ & $\begin{array}{l}156.00 \pm 1.00(495 \\
\mu \mathrm{M})\end{array}$ & $19.50 \pm 0.57(61.9 \mu \mathrm{M})$ \\
\hline 3 & $>5000(9487 \mu \mathrm{M})$ & $>5000(9487 \mu \mathrm{M}]$ & $>5000(9487 \mu \mathrm{M})$ \\
\hline 4 & $\begin{array}{l}39.00 \pm 0.13(56.60 \\
\mu \mathrm{M})\end{array}$ & $\begin{array}{l}9.70 \pm 0.36(14.07 \\
\mu \mathrm{M})\end{array}$ & $312.00 \pm 1.04(452 \mu \mathrm{M})$ \\
\hline 5 & $>5000(9823 \mu \mathrm{M})$ & $>5000(9823 \mu \mathrm{M})$ & $>5000(9823 \mu \mathrm{M})$ \\
\hline$* *$ Fluconazole & $\begin{array}{l}2.00 \pm 0.01(6.53 \\
\mu \mathrm{M})\end{array}$ & $\begin{array}{l}8.00 \pm 0.25(26.14 \\
\mu \mathrm{M})\end{array}$ & $32.00 \pm 0.42(10.45 \mu \mathrm{M})$ \\
\hline
\end{tabular}

*Plant extracts were tested using the CLSI M27-A3 [6] protocol. Activity was expressed as minimal inhibitory concentration at which there were no visible fungal growth; $* *$ Reference used as positive control.

The flash chromatography of the crude extract generated 4 fractions exhibiting varying antifungal activities. As shown in table 1, fraction T3 was the most active, with activity magnification over 100 times against $C$. parapsilosis and C. krusei (MIC: $0.16 \mu \mathrm{g} / \mathrm{mL}$ and 0.02 $\mu \mathrm{g} / \mathrm{mL}$ respectively) and over 60 times against C. albicans $(0.64 \mu \mathrm{g} / \mathrm{mL})$. C. krusei was the most susceptible isolate to fraction T3. Compounds $\mathbf{1 ,} \mathbf{2}, \mathbf{3}, \mathbf{4}$, and $\mathbf{5}$ that were isolated from fractions T1-T3 and were also tested for biological activity (Table 1; Figure 1). Compounds 6 and 7 were not tested due to reduced solubility in the culture medium. From the results achieved, compounds $\mathbf{1}$ and $\mathbf{4}$ showed the best potency against C. albicans with MIC of 9.7 $\mu \mathrm{g} / \mathrm{ml}$. They also moderately inhibited C. parapsilosis with an MIC of $39 \mu \mathrm{g} / \mathrm{ml}$. Besides, compound 2 inhibited C. krusei with an MIC of $19.5 \mu \mathrm{g} / \mathrm{ml}$. 


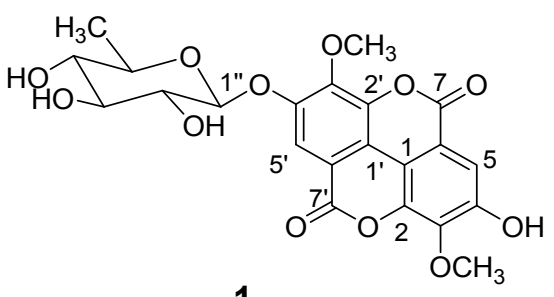

1

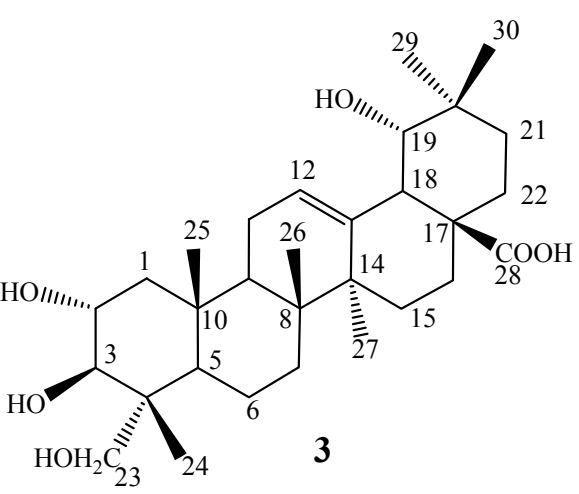

1a: $\mathrm{R}=\mathrm{H}$

2: $\mathrm{R}=\mathrm{CH}_{3}$<smiles></smiles>

$\mathrm{COH}_{23}$

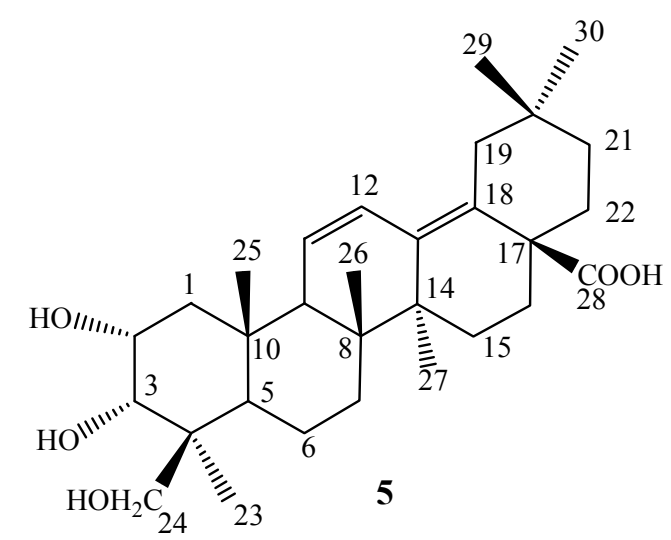<smiles>CC[C@H](/C=C/[C@@H](C)[C@H]1CCC2C3CC=C4C[C@@H](O)CC[C@]4(C)C3CC[C@@]21C)C(C)C</smiles>

6

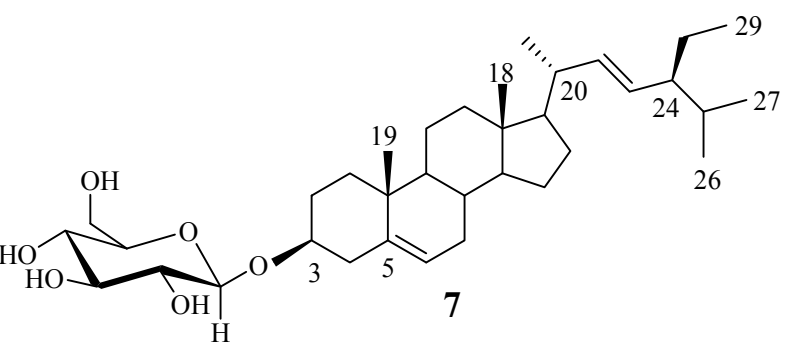

Fig.1. Structures of the isolated compounds 1-7 from Terminalia mantaly (Combretaceae)

The isolated compounds were tested against pathogenic yeast isolates and enzymes of metabolic significance. 1: IC $50=39$ $\mu \mathrm{g} / \mathrm{mL}$ C. parapsilosis; $9.7 \mu \mathrm{g} / \mathrm{mL}$ C. albicans; $>5 \mu \mathrm{g} / \mathrm{mL}$ C. krusei; CAI: $\mathrm{IC}_{50}=53.31 \mu \mathrm{M}, \mathrm{Ki}=44.11 \mu \mathrm{M}$; CAII: IC $50=69.11$ $\mu \mathrm{M}, \mathrm{Ki}=55.78 \mu \mathrm{M}$; GST: $\mathrm{IC}_{50}=63.01 \mu \mathrm{M}, \mathrm{Ki}=42.00 \mu \mathrm{M}$. 2: $\mathrm{IC}_{50}=78 \mu \mathrm{g} / \mathrm{mL}$ C. parapsilosis; $156 \mu \mathrm{g} / \mathrm{mL}$ C. albicans; 19.5 $\mu \mathrm{g} / \mathrm{mL}$ C. krusei. 3: . parapsilosis, C. albicans, krusei: $\mathrm{IC}_{50}>5000 \mu \mathrm{g} / \mathrm{mL} ; \mathrm{CAI}: \mathrm{IC}_{50}=86.64 \mu \mathrm{M}, \mathrm{Ki}=71.68 \mu \mathrm{M}$; GST: IC $50=$ $1.51 \mu \mathrm{M}, \mathrm{Ki}=1.00 \mu \mathrm{M}$. 4: $\mathrm{IC}_{50}=39 \mu \mathrm{g} / \mathrm{mL}$ C. parapsilosis; $9.7 \mu \mathrm{g} / \mathrm{mL}$ C. albicans; $312 \mu \mathrm{g} / \mathrm{mL}$ C. krusei; G6PD: IC $\mathrm{I}_{50}=1.84$ $\mu \mathrm{M}, \mathrm{Ki}=0.19 \mu \mathrm{M}$; CAI: $\mathrm{IC}_{50}=3.28 \mu \mathrm{M}, \mathrm{Ki}=2.72 \mu \mathrm{M}$; CAII: $\mathrm{IC}_{50}=1.28 \mu \mathrm{M}, \mathrm{Ki}=1.03 \mu \mathrm{M}$; GST: $\mathrm{IC}_{50}=1.84 \mu \mathrm{M}, \mathrm{Ki}=1.23$ $\mu \mathrm{M}$.

\section{NMR spectral data of compounds 1-5}

\section{3-O- methylellagic acid 4'-O- $\alpha$-rhamnopyranoside (1) [36]}

Yellowish powder; molecular formula $\mathrm{C}_{21} \mathrm{H}_{18} \mathrm{O}_{12}$; ESI-MS: [M+Na] ${ }^{+} \mathrm{m} / z \quad 485,049{ }^{1} \mathrm{H}$ NMR (300 MHz, DMSO- $\left.d_{6}\right): \delta_{\mathrm{H}} 1.13\left(3 \mathrm{H}, \mathrm{d}, \mathrm{CH}_{3}, \mathrm{H}-6{ }^{\prime \prime}\right), 3.54(1 \mathrm{H}, \mathrm{q}, J=8,0$ and 12,0 Hz, H-5"), 4.01 (1H, t, H-4"), 4.04 (3H, s, OMe-3), 4.72 (1H, brd, $J=8,0$ Hz, H-3"), 4.94 (1H, brd, $J=4,0$ Hz, H-2"), 5.47 (1H, brs, H-1"), 7.52 (1H, s, H-5), 7.73 (1H, s, H-5'); ${ }^{13} \mathrm{C}$ NMR (125 MHz, 
DMSO- $d_{6}$ ), aglycone moiety: $\delta_{\mathrm{C}} 113.4$ (C-1), 140.5 (C-2), 141.8 (C-3), 153.1 (C-4), 111.9 (C5), 113.4 (C-6), 159.1 (C-7), 114.7 (C-1'), 136.6 (C-2'), 142.2 (C-3'), 146.9 (C-4'), 112.0 (C-5'), 107.4 (C-6'), 159.1 (C-7'); rhamnose moiety: 100.5 (C-1"), 70.4 (C-2"), 70.5 (C-3"), 72.2 (C4"), 70.3 (C-5"), 18.3 (C-6") and 61.4 (C-3, OMe).

\section{3-O-methyl ellagic acid (2) [36]}

Yellowish powder; molecular formula $\mathrm{C}_{15} \mathrm{H}_{8} \mathrm{O}_{8}$; ESI-MS: [M-H] $]^{-} \mathrm{m} / z$ 315, 1H NMR (DMSO-d6): $\delta 7.50$ (1H, s,H-5), 7.44 (1H, s, H-5'), 4.02 (3H, s, 3-OMe). 13C NMR (DMSO-d6): $\delta 158.9$ (C-7), 158.6 (C-7'), 152.2 (C-4), 148.2 (C-4'), 141.7 (C-2), 140.0 (C-3), 139.8 (C-3'), 136.1 (C-2'), 112.4(C-1'), 112.1 (C-6), 111.7 (C-1), 111.3 (C-5), 110.1 (C-5'), $107.2\left(\mathrm{C}-6^{\prime}\right), 60.8(3-\mathrm{OMe})$.

\section{Arjungenin or 2,3,19,23-tetrahydroxyolean-12-en-28-oic acid (3) [37]}

White powder; molecular formula $\mathrm{C}_{30} \mathrm{H}_{48} \mathrm{O}_{6}$; ESI-MS: [M+Na] ${ }^{+} \mathrm{m} / z$ 527,322. ${ }^{1} \mathrm{H}$ NMR (300 MHz, DMSO- $\left.d_{6}\right): \delta_{\mathrm{H}} 1.23,1.09,0.90,0.88,0.84$ and 0.65 (each $\left.3 \mathrm{H}, \mathrm{s}\right) ; 2.92$ (1H, brs, H-18); $2.86(1 \mathrm{H}, \mathrm{d}, J=8 \mathrm{~Hz}, \mathrm{H}-3)$ and $3.57(1 \mathrm{H}, \mathrm{m}, \mathrm{H}-2) ; 5.23$ (1H, brs, H-12); ${ }^{13} \mathrm{C} \mathrm{NMR}(125 \mathrm{MHz}$; DMSO- $\left.d_{6}\right): \delta_{\mathrm{C}} 16.8,17.1,23.9,24.9,28.9$ and 24.5; 64.3 (C-23), 80.5 (C-3), 179.6 (C-28), $122.6(\mathrm{C}-12) ; 143.9$ (C-13).

\section{2,3,19,23-tetrahydroxyolean-12-en-28-oic acid (4) [38]}

White powder; molecular formula $\mathrm{C}_{36} \mathrm{H}_{58} \mathrm{O}_{11}$; ESI-MS: [M+Na] ${ }^{+} m / z 689,396$; ${ }^{1} \mathrm{H}$ NMR (300 MHz, DMSO- $d_{6}$ ): $\delta 1.23,1.08,0.89,0.86,0.84$ and 0.63 (each $3 \mathrm{H}, \mathrm{s}$ ); between 2.90 and 3.80: glucose moiety with anomeric proton at 5,20 $\left(1 \mathrm{H}, \mathrm{d}, J=6.9 \mathrm{~Hz}, \mathrm{H}-1^{\prime}\right) ;{ }^{13} \mathrm{C} \mathrm{NMR}(125 \mathrm{MHz}$; DMSO- $\left.d_{6}\right): \delta 16.9,24.5,24.9$ and 28.5; glucose moiety: 61.0, 69.9, 72.8, 77.1, 78.2, 94.5; 64.3 (C-23), 67.4 (C-2), 80.4 (C-3), 176.3 (C-28), 122.6 (C-12), 143.7 (C-13).

\section{2 $\alpha, 3 \alpha, 24-t r i h y d r o x y o l e a n-11,13$ (18)-dien-28-oic acid (5) [39]}

Yellowish powder; molecular formula $\mathrm{C}_{30} \mathrm{H}_{46} \mathrm{O}_{5}$; ESI-MS: [M+Na] ${ }^{+} m / z$ 509,375 (calc. $509,324)$ for $\left.\mathrm{C}_{30} \mathrm{H}_{46} \mathrm{NaO}_{5}\right) ;{ }^{1} \mathrm{H} \mathrm{NMR}\left(400 \mathrm{MHz}\right.$; pyridin- $\left.d_{5}\right): \delta 1.58 ; 1.06 ; 1.05 ; 1.03 ; 0.90$ and 0.87 (each 3H, s); $6.62(1 \mathrm{H}, \mathrm{d}, J=8.0 \mathrm{~Hz}, \mathrm{H}-11)$ and $5.81(1 \mathrm{H}, \mathrm{d}, J=8.0 \mathrm{~Hz}, \mathrm{H}-12) ; 4.38(1 \mathrm{H}$, ddd, $J=2.2$;7.6 and $8.9 \mathrm{~Hz}, \mathrm{H}-2) ; 3.59$ (1H, d, $J=7.5 \mathrm{~Hz}, \mathrm{H}-3) ; 4.43$ (1H, d, $J=8.7 \mathrm{~Hz}, \mathrm{H}-24)$ and $3.75(1 \mathrm{H}, \mathrm{d}, J=8,76 \mathrm{~Hz}, \mathrm{H}-24) ; 2.69(1 \mathrm{H}, \mathrm{d}, J=12.4 \mathrm{~Hz}, \mathrm{H}-19)$ and $2.15(1 \mathrm{H}, \mathrm{d}, J=12.4$ Hz, H-19); ${ }^{13} \mathrm{C}$ NMR (125 MHz; pyridin- $\left.d_{5}\right)$ : $\delta_{\mathrm{C}} 16.6,19.5,19.8,23.7,24.0$ and 32.1; 65.1 (C- 
24), 68.4 (C-2), 85.5 (C-3), 178,6 (C-28) ;136,1 (C-13); 133,3 (C-18) ; 126,4 (C-12) et 125,9 (C-11).

Apart from the activity profile described above, MIC values for the other tested fractions and compounds were above $39 \mu \mathrm{g} / \mathrm{ml}$. The activity of compounds $\mathbf{1}$ and $\mathbf{4}$ was comparable to that of the reference drug fuconazole against $C$. albicans and, compound $\mathbf{2}$ showed to be over 1.5 times more active than the same reference drug against $C$. krusei. Based on basic skeleton of the tested compounds, it is important to notice that one of the most active derivatives, $\mathbf{4}$ and the less active compounds, $\mathbf{3}$ and $\mathbf{5}$ are all triterpenoids. Preliminary structure-activity relationship (SAR) study clearly indicated that the glycosylation of the acidic function of compound $\mathbf{3}$ at C-28 is important for activity improvement. The other active compounds $\mathbf{1}$ and $\mathbf{2}$ are ellagic acid derivatives. Previous studies have reported the antifungal activity of ellagic acid (1a) against fungal strains Trichophyton rubrum, T. verrucosum, T. mentagrophytes, T. violaceum, T. schoenleinii, Microsporum canis, C. glabrata, C. albicans and C. tropicalis [40]. Also, the observed antifungal potency of compounds $\mathbf{1}$ and $\mathbf{2}$, respectively glycosylated and methylated derivatives of 1a highlights the potency of this class of secondary metabolites [40].

Overall, it was observed that fraction T3 exerted the more potent effect against the tested yeasts, far better than the derived compounds. This is an indication that fractionation has declined the anti-yeast activity, emphasizing the relevance of potential synergistic interactions among the components of fraction T3. Moreover, these results indicate future directions in the progression of this fraction to develop a phytodrug against yeasts infections.

Selected isolated compounds were further tested against G6PD, Carbonic anhydrase I, II and GST enzymes. The results achieved are shown in table 2.

Table 2: Inhibitory parameters of isolated compounds against G6PD, CAI, CAII, and GST

\begin{tabular}{|c|c|c|c|c|c|c|c|c|c|c|c|c|c|c|c|c|}
\hline & \multicolumn{4}{|c|}{ G6PD } & \multicolumn{4}{|l|}{ CAI } & \multicolumn{4}{|l|}{ CAII } & \multicolumn{4}{|l|}{ GST } \\
\hline & 1 & 2 & 3 & 4 & 1 & 2 & 3 & 4 & 1 & 2 & 3 & 4 & 1 & 2 & 3 & 4 \\
\hline${ }^{\mathrm{a}} \mathrm{IC}_{50}(\mu \mathrm{M})$ & n.a & na & na & $\begin{array}{l}1.84 \pm \\
0.31\end{array}$ & $\begin{array}{l}53.31 \pm \\
1.09\end{array}$ & & $\begin{array}{l}86.64 \pm \\
0.93\end{array}$ & $\begin{array}{l}3.28 \pm \\
0.13\end{array}$ & $\begin{array}{l}69.31 \pm \\
1.13\end{array}$ & na & na & $\begin{array}{l}1.03 \pm \\
0.01\end{array}$ & $\begin{array}{l}63.01 \pm \\
1.15\end{array}$ & na & $\begin{array}{l}1.51 \pm \\
0.78\end{array}$ & $\begin{array}{l}1.84 \pm \\
0.73\end{array}$ \\
\hline${ }^{\mathrm{b}} \mathrm{Ki}(\mu \mathrm{M})$ & n.a & na & na & $\begin{array}{l}0.19 \pm \\
0.03\end{array}$ & $\begin{array}{l}44.11 \pm \\
1,12\end{array}$ & & $\begin{array}{l}71.68 \pm \\
0.96\end{array}$ & $\begin{array}{l}2.72 \pm \\
0.64\end{array}$ & $\begin{array}{l}55.78 \pm \\
0.97\end{array}$ & na & na & $\begin{array}{l}1.84 \pm \\
0.11\end{array}$ & $\begin{array}{l}42.00 \pm \\
1.39\end{array}$ & na & $\begin{array}{l}1.00 \pm \\
0.03\end{array}$ & $\begin{array}{l}0.19 \pm \\
0.77\end{array}$ \\
\hline
\end{tabular}

Enzymes were expressed and purified, and subsequently assessed for in vitro susceptibility to inhibitors. ${ }^{\text {aSerially }}$ diluted triplicate concentrations were tested and activity expressed as 50\% inhibitory concentration. ${ }^{\mathrm{b} I n h i b i t o r y}$ constant which is reflective of the binding affinity; the smaller the $\mathrm{Ki}$, the greater the binding affinity and the smaller amount of medication needed in order to inhibit the activity of that enzyme.n.a= non active.

The G6PD enzyme was strongly inhibited by the triterpenoid arjunglucoside (4) with $\mathrm{IC}_{50}$ value of $1.84 \mu \mathrm{M}$ and $\mathrm{Ki}$ (the inhibitor constant indicating how potent an inhibitor is; or 
the concentration required to produce half maximum inhibition) value of $0.19 \mu \mathrm{M}$. It has been shown that this key metabolic enzyme which catalyzes the first step of pentose phosphate pathway is expressed abundantly and very active in human tumors [21]. In contrast, G6PDdeficient tumor cell lines showed relatively slow growth and enhanced apoptosis [41]. Previous studies also reported G6PD inhibitory properties for few compounds such as steroids and derivatives [42, 43], chalcones [28], catechin gallates [44], and some phenolic molecules [45]. In this study, the substituted ellagic acid derived compound $\mathbf{1}$ did not show any effect on the G6PD enzyme activity, although Adem et al [45] reported that ellagic acid inhibited the enzyme with an $\mathrm{IC}_{50}$ value of $0.072 \mathrm{mM}$. The methoxy group in compound 1 may hindrance the enzyme-inhibitor interaction. Based on the skeletal features of the tested triterpenoids $\mathbf{3}, \mathbf{4}$, $\mathbf{5}$, the presence of hydroxyl group at C-19 and the glycosylation of C-28 carboxylic group may be both factors of activity improvement. The G6PD inhibitory potential of a terpenoid is reported here for the first time.

Compound 4 exhibited very good potency against both hCAI and hCA II enzymes with respective activity parameters of $\mathrm{IC}_{50}=3.28 \mu \mathrm{M}$ and $\mathrm{Ki}=2.72 \mu \mathrm{M}$; and $\mathrm{IC}_{50}=1.28 \mu \mathrm{M}$ and $\mathrm{Ki}=$ $1.03 \mu \mathrm{M}$ respectively. The other tested compounds including 3-O-methyl-4-O- $\alpha$ rhamnopyranoside ellagic acid (1) and arjungenin (3) were found to be moderately active against hCAI and hCA II (compound 1) with $\mathrm{IC}_{50}$ and $\mathrm{Ki}$ values globally above $44 \mu \mathrm{M}$. Previous studies by Sarkaya et al [46] have indicated that ellagic acid inhibited hCA I and hCA II with $\mathrm{K}_{\mathrm{i}}$ values of 0.207 and $0.146 \mathrm{mM}$ respectively. In the present study, compound 1, a substituted derivative of ellagic acid (1a) has exhibited moderate, however highly improved potency toward hCA I $(\mathrm{Ki}=44.11 \mu \mathrm{M})$ and hCA II $(55.78 \mu \mathrm{M})$ enzymes. However, this substitution has also considerably decreased the activity as observed against the G6PD enzyme. In addition to the established role of CA inhibitors (CAIs) as diuretics and antiglaucoma drugs, it has recently emerged that they could have potential as novel anti-obesity, anticancer and antiinfective drugs [47]. The high inhibitory potency of the triterpenoid 4 against CAs indicates that it is a promising compound that might be progressed for the formulation of drugs against CAIs-related diseases.

The screening of 3-O-methyl-4-O- $\alpha$-rhamnopyranoside ellagic acid (1), arjungenin (3), and arjunglucoside (4) against GST enzyme showed inhibitory effects. However, the triterpenoids 3 and 4 exhibited highly potent inhibitory effects $\left(\mathrm{IC}_{50 \mathrm{~S}}\right.$ of 1.57 and $1.84 \mu \mathrm{M}$ respectively; and $\mathrm{Ki}$ of 1.00 and $1.23 \mu \mathrm{M}$ respectively). Compound $\mathbf{1}$ only exerted a moderate inhibitory effect on the enzyme $\left(\mathrm{IC}_{50}=63.01 \mu \mathrm{M} ; \mathrm{Ki}=42.00 \mu \mathrm{M}\right)$. These results are of higher significance as GST inhibitors are anti-cancer agents $[25,26]$. Ellagic acid (1a) was recently 
shown to inhibit GSTs A1-1, A2-2, M1-1, M2-2 and P1-1 with $\mathrm{IC}_{50}$ values ranging from 0.04 to $5 \mu \mathrm{M}$ [48]. Preliminary SAR studies indicate that the substitution of ellagic acid at C-3 and C-4' gave derivative 1 which showed an $\mathrm{IC}_{50}$ value of $63.01 \mu \mathrm{M}$ ), thus therefore considerably decreased the activity. The inhibitory effect of this class of secondary metabolite derivatives is reported here for the first time.

\section{Concluding remarks}

The results obtained from the investigation of the methanolic extract of Terminalia mantaly stem bark have identified a highly potent anti-yeast fraction T3 that showed to be more promising than subsequently isolated compounds. This promising fraction deserves to be further investigated with the ultimate aim of formulating a plant-based drug against yeasts infections. Compounds $\mathbf{1}$ and $\mathbf{4}$ showed anti-yeast activity close to that of the reference drug fuconazole against $C$. albicans. Moreover, compound 2 was over 1.5 times more active than fuconazole against C. krusei. Besides, two of the islotated compounds, arjungenin (3) and arjunglucoside (4) were found to be very active against enzymes of metabolic significance, including G6PD (compound 4) and GST (compounds 3 and 4). Finally, given the anti-yeast potency of these compounds, and also the implication of the tested enzymes in some metabolic dysfunctions of public health significance (cancer, obesity, epilepsy), we envisage further SAR studies to identified potent hit derivatives that should subsequently enter drug development pipeline.

\section{Author contributions}

NS, ET, BNL, FFB, and SAN designed and supervised the study; MATT, TNK, SG, RMTK, AA, MK, VC, RD performed the chemical and biological parts of the study and drafted the manuscript; BNL and FFB critically revised the manuscript. All authors agreed on the final version of the manuscript for submission to Medicines.

\section{Compliance with ethical standards}

The authors declare no competing interest.

\section{Acknowledgement}

The authors acknowledge the Alexander von Humboldt Foundation for providing a Fellowship to B. N. Lenta at Bielefeld University. Part of this study was supported by equipment from the Seeding Labs’ Instrumental Access Grant (SL2012-2) to FF Boyom. 


\section{References}

[1]- Arif, T.; Mandal, T.K.; Dabur R. Natural products: Anti-fungal agents derived from Plants. In: Pandalai, S.G. (ed.). Opportunity, Challenge and Scope of Natural Products in Medicinal Chemistry. Research Signpost, Trivandrum, Kerala, India, 2011, pp. 283-311.

[2]-Nelesh, G. HIV-associated opportunistic fungal infections: a guide to using the clinical microbiology laboratory. South. Arf. J. HIV Med. 2007, 1, 18-23.

[3]-Álvaro-Meca, A.; Jensen, J.; Micheloud, D.; Asunción, D.; Gurbindo, D.; Resino, S. Rate of candidiasis among HIV infected children in Spain in the era of highly active antiretroviral therapy (1997-2008). BMC Inf. Dis. 2013, 13, 1-15.

[4]-Brissaud, O. ; Guichoux, J. ; Harambat, J. ; Tandonnet, O. ; Zaoutis, T.. Invasive fungal disease in PICU: epidemiology and risk factors. Ann. Intensive Care 2012, 2, 6.

[5]-Ngouana, K.T.; Krasteva, D.; Drakulovski, P.; Toghueo, K.R.; Kouanfack, C.; Ambe, A.; Reynes, J.; Delaporte, E.; Boyom, F.F.; Mallié, M.; Bertout, S. Investigation of minor species Candida africana, Candida stellatoidea, and Candida dubliniensis in the Candida albicans complex among Yaoundé (Cameroon) HIV-infected patients. Mycoses 2015, 58, 33-39.

[6]-Ngouana, K.T.; Dongtsa, J.; Kouanfack, C.; Tonfack, C.; Foména, S.; Krasteva, D.; Drakulovski, P.; Aghokeng, A.; Mallié, M.; Delaporte, E.; Boyom, F.F.; Bertout, S.. Cryptoccocal meningitis in Yaoundé (Cameroon) HIV infected patients: Diagnosis, frequency and susceptibility of Cryptococcus neoformans isolates to fluconazole. J. Mycol. Med. 2015, 25, 11-16.

[7]-Newman, D.J.; Cragg, G.M.. Natural products as sources of new drugs over the last 25 years. J. Nat. Prod. 2007, 70, 461-477.

[8]-Coulibaly, K. Evaluation of the antifungal activity of extracts of bark of commercial species, category P1 the forest of Mopri, Tiassalé (Southern Ivory Coast). Master Memory, University of Cocody-Abidjan. 2006, pp. 23-25.

[9]- Cock, I.E.; Van-Vuuren, S.F.. A comparison of the antimicrobial activity and toxicity of six Combretum and two Terminalia species from Southern Africa. Pharmacogn Mag. 2015, 11, 208-218.

[10]- Cock, I. The medicinal properties and phytochemistry of plants of the genus Terminalia (Combretaceae). Inflammopharmacol 2015, 23, 203-229.

[11]-Valsaraj, R.; Pushpangadan, P.; Smitt, U.W.; Adsersen, A.; Christensen, S.B.; Sittie, A.; Nyman, U.; Nielsen, C.; Olsen, C.E. New anti-HIV-1, antimalarial and antifungal compounds from Terminalia bellerica. J. Nat. Prod. 1997, 60, 739-742. 
[12]-Srivastava, S.K.; Srivastava, S.D.; Chouksey, B.K.New constituents of Terminalia alata. Fitoterapia 1999, 70, 390-394.

[13]-Conrad, J.; Vogler, B.; Klaiber, I.; Roos, G.; Walter, U.; Kraus, W.Two triterpene esters from Terminalia macroptera bark. Phytochemistry 1998, 48, 647-650.

[14]-Conrad, J.; Vogler, B.; Reeb, S.; Klaiber, I.; Papajewski, S.; Roos, G.; Vasquez, E.; Setzer, M.C.; Kraus, W. Isoterchebulin and 4,6-O-isoterchebuloyl-D-glucose, Novel Hydrolyzable Tannins from Terminalia macroptera. J. Nat. Prod. 2001, 64, 294- 299.

[15]-Kandil, F.E.; Nassar, M.I. A tannin anti-cancer promotor from Terminalia arjuna. Phytochemistry 1998, 47, 1567-1568.

[16]-Mahato, S.B.; Nandy, A.K.; Kundu, A.H. Pentacyclic triterpenoids sapogenols and their glycosides from Terminalia bellerica. Tetrahedron 1992, 48, 2483-2484.

[17]-Singh, D.V.; Verma, R.K.; Singh, C.S.; Gupta, M.M.. RP-LC determination of oleane derivatives in Terminalia arjuna. J. Pharm. Biomed. Anal. 2002, 28, 183-452.

[18]-Garcez, R.F. ; Garcez, S.W. ; Santana, A.L.B.D.; Alves, M.M. ; Matos, M.F.C.C. ; Scaliante, A.M. Bioactive flavonoids and triterpenes from Terminalia fagifolia (Combretaceae). J. Braz. Chem. Soc. 2006, 17, 1223-1228.

[19]-Yeh, G.C.; Daschner, P.J.; Lopaczynska, J.; MacDonald, C.J.; Ciolino, H.P. Modulation of glucose-6-phosphate dehydrogenase activity and expression is associated with aryl hydrocarbon resistance in vitro. J. Biol. Chem. 2001, 276, 34708-34713.

[20]-Matsubara, S.; Kato, T.; Oshikawa, K.; Yamada, T.; Takayama, T.; Koike, T.; Sato, I. Glucose-6-phosphate dehydrogenase in rat lung alveolar epithelial cells. An ultrastructural enzyme-cytochemical study. Eur. J. Histochem. 2002, 46, 243-8.

[21]-Preuss, J.; Richardson, A.D.; Pinkerton, A.; Hedrick, M.; Sergienko, E.; Rahlfs, S.; Bode,

L. Identification and characterization of novel human glucose-6-phosphate dehydrogenase inhibitors. J. Biomol. Screen. 2013, 18, 286-297.

[22]-Tripp, B.C.; Smith, K.; Ferry, J.G. Mini review: carbonic anhydrase: new insights for an ancient enzyme. J. Biol. Chem. 2001, 276, 48615-48618.

[23]-Supuran, C.T. Carbonic anhydrases: novel therapeutic applications for inhibitors and activators. Nat. Rev. Drug Discov. 2008, 7, 168-181.

[24]-Comakli, V.; Ciftci, M. ; Kufrevioglu, O.I. Effects of some metal ions on rainbow trout erythrocytes glutathione $S$-transferase enzyme: an in vitro study. J. Enzyme inhib. Med. Chem. 2013, 28, 1261-1266.

[25]- Mannervik, B.; Danielson, U.H. Glutathione transferases - structure and catalitic activity. CRC Crit. Rev. Biochem. 1988, 23, 283-337. 
[26]-Matshushita, N.; Aritake, K.; Takada, A.; Hizue, M.; Hayashi, K.; Mitsui, K. Pharmacological studies on the novel antiallergenic drug HQL-79: 2. Elucidation of mechanisms for antiallergic and antiasthmatic effects. Jpn J. Pharmacol. 1998, 78, 11-22. [27]-Hayes, J.D.; McLellan, L.I.; Stockman, P.K.; Chalmers, J.; Beckett, G.J. Glutathione Stransferases in man: The relationship between rat and human enzymes. Biochem. Soc. Trans. 1987, 15, 721-725.

[28]-Kuzu, M.; Aslan, A.; Ahmed, I.; Comakli, V.; Demirdag, R.; Uzun, N. Purification of glucose-6-phosphate dehydrogenase and glutathione reductase enzymes from the gill tissue of Lake Van fish and analyzing the effects of some chalcone derivatives on enzyme activities. Fish Physiol. Biochem. 2016, 42, 483-491.

[29]-Beutler, E.. Red cell metabolism: a manual of biochemical methods (3rd ed.) Grune and Stratton Inc., Orlando, 1984, pp. 68-70.

[30]-Ekinci, D.; Cavdar, H. ; Talaz, O. ; Sentürk, M. ; Supuran, C.T. NO-releasing esters show carbonic anhydrase inhibitory action against human isoforms I and II. Bioorg. Med. Chem. 2010, 18, 3559-3563.

[31]-Verpoorte, J.A.; Mehta, S.; Edsall, J.T. Esterase activities of human carbonic anhydrases B and C. J. Biol. Chem. 1976, 242, 4221-4229.

[32]-Hunaiti, A.A.; Soud, M. Effect of lead concentration on the level of glutathione, glutathione S-transferase, reductase and peroxidase in human blood. Sci. Total Environ. 2000, $248,45-50$

[33]-Güvercin, S.; Erat, M.; Sakiroglu, H. Determination of some kinetic and characteristic properties of glutathione $S$-transferase from bovine erythrocytes. Protein Pept. Lett. 2008, 15, $6-12$.

[34]-Habig, W.H.; Pabst, M.J.; Jakoby, W.B. Glutathione S-transferases. The first enzymatic step in mercapturic acid formation. J. Biol. Chem. 1974, 249, 7130-7139.

[35]-Cheng, Y.; Prusoff, W.H. Relationship between the inhibition constant (K1) and the concentration of inhibitor which causes 50 per cent inhibition (I50) of an enzymatic reaction. Biochem. Pharmacol. 1973, 22, 3099-108.

[36]-Liu, M.; Katerere, R.D.; Gray, I.A.; Seidel, V. Phytochemistry and antifungal studies on Terminalia mollis and Terminalia brachystemina. Fitoterapia, 2009, 80, 369-373.

[37]-Nandy, A.K.; Podder, G.; Sahu, N.P.; Mahato, S.B. Triterpenoids and their glycosides from Terminalia bellerica. Phytochemistry, 1989, 28, 2769-2772.

[38]-Jossang, A.; Seuleiman, M.; Maidou, E.; Bodo, B. Pentacyclic triterpenes from Combretum nigricans. Phytochemistry 1996, 41,591-594. 
[39]-Kojima, H.; Tominaga, H.; Sato, S.; Ogura, H. Pentacyclic triterpenoids from Prunella vulgaris. Phytochemistry 1987, 26, 1107-1111.

[40]-Li, Z.; Guo, X.; Dawuti, G.; Aibai, S. Antifungal activity of ellagic acid in vitro and in vivo. Phytother. Res. 2015, 29, 1019-1025.

[41]-Kuo, W.Y.; Lin, J.Y.; Tang, K. Human glucose-6-phophate dehydrogenase (G6PD). Gene transforms NIH 3 T3 cells and induces tumors in nude mice. Int. J. Cancer 2000, 85, 857-864. [42]-Gupta, S.; Cordeiro, T.A.; Michels, P.A.M. Glucose-6-phosphate dehydrogenase is the target for the trypanocidal action of human steroids. Mol. Biochem. Parasitol. 2011, 176, 112 115.

[43]-Hamilton, M.N.; Dawson, M.; Fairweather, E.E.; Hamilton, S.N.; Hitchin, R.J.; James, I.D.; Jones, D.S.; Jordan, M.A.; Lyones, J.A.; Small, F.H. Novel steroid inhibitors of glucose 6phosphate dehydrogenase. J. Med. Chem. 2012, 55, 4431-4445.

[44]-Shin, E.S.; Park , J.; Shin, J.M.; Cho, D.; Cho, S.Y.; Shin, D.W.; Ham, M.; Kim, J.B.; Lee, T.R. Cathechin gallates are NADP+-competitive inhibitors of glucose-6-phosphate dehydrogenase and other enzymes that employ NADP+ as a coenzyme. Bioorg. Med. Chem. 2008, 16, 3580-3586.

[45]-Adem, S.; Comakli, V.; Kuzu, M.; Demirdag, R. Investigation of the effects of some phenolic compounds on the Activities of glucose-6-phosphate dehydrogenase and 6Phosphogluconate dehydrogenase from human erythrocytes. J. Biochem. Mol. Toxicol. 2014, $28,510-514$.

[46]-Beyza, Ö.S.; Gülçin, İ.; Supuran, C.T. Carbonic anhydrase inhibitors: Inhibition of human erythrocyte isozymes I and II with a series of phenolic acids. Chem. Biol. Drug Des. 2010, 75, 515-520.

[47]-Supuran, C.T. Carbonic anhydrases: novel therapeutic applications for inhibitors and activators. Nat. Rev. Drug Discov. 2009, 7, 168-181.

[48]- Hayeshi, R.; Mutingwende, I.; Mavengere, W.; Masiyanise, V.; Mukanganyama, S. The inhibition of human glutathione S-transferases activity by plant polyphenolic compounds ellagic acid and curcumin. Food Chem. Toxicol. 2007, 45(2), 286-95.

(C) 2016 by the authors; licensee Preprints, Basel, Switzerland. This article is an open access article distributed under the terms and conditions of the Creative Commons by Attribution (CC-BY) license (http://creativecommons.org/licenses/by/4.0/). 